\title{
Performance of Anthurium (Anthurium anderanum Lindl) cultivars under hill zone of Karnataka
}

\author{
S.K. Nataraj, Kirtimala B. Naik, H.S. Yallesh Kumar and Y.S. Ramesha \\ College of Horticulture, Mudigere-Karnataka - 577132 \\ *E-mail: natflori@gmail.com
}

\begin{abstract}
An investigation was carried out at experimental block, College of Horticulture, Mudigere. Tropical recorded maximum LAI 2.83, and had maximum plant height, number of leaves, leaf area and Leaf area Index. Cultivar Crinkle Red recorded maximum number of flowers per plant per year (13.14), which was on par with Tropical (11.77), Cheers (10.60) and Fire (10.25). Cultivar Midori recorded maximum vase life (35.00 days) followed by Tropical (33.33 days) and it was on par with Fire (32.22 days). Cultivar Midori recorded maximum vase life (35.00 days), followed by Tropical (33.33 days) and it was on par with Fire (32.22 days) and highest $B$ : $C$ ratio is recorded in cultivar Tropical (1.83) and it was least in Fantacia (1.13) .
\end{abstract}

Keywords: Anthurium, Protected cultivation, Economics

\section{INTRODUCTION}

Anthurium (Anthurium andreanum Lind) is cultivated for its colour full spathe and attractive foliage, Anthuriumis having 600 species distributed worldwide. It is grown for different purposes among them Anthurium andreanum is popular for cut flower (Shiva and Sujatha, 2008). The major producers in the world are Netherland, Mauritius and Hawaii. Asia is most rapidly growing market for Anthurium. It is basically a semiterrestrial tropical plant requiring warm, shaded and humid conditions, similar conditions that prevail in West Coast and Western ghat hilly regions of South India. Commercial cultivation of Anthurium started by coffee planters of Karnataka, Kerala and Tamil $\mathrm{Nadu}$. It comes up well under temperatures of 21$24{ }^{\circ} \mathrm{C}$, relative humidity of $60-80 \%$ with low to medium light intensity of 20000 to 25000 Lux and very importantly quality flowers with bright colour, good stalk length. Growth \& yield can be achieved at 60 to $80 \%$ shade in different seasons (Prakash et al., 2006). Though coffee is the major crop in hilly regions of Karnataka lot of fluctuation exists in price and due to labour problem planters are looking for an alternative crop, with this back ground present study was carried out to find out suitable varieties for hill zone of Karnataka under NVPH.

The present investigation was carried out at experimental block, College of Horticulture, Mudigere which is situated in hill zone of Karnataka at 130 7' $^{\prime}$ North latitude, $75037^{\prime}$ East longitude with an altitude of $982 \mathrm{~m}$ above mean sea level which receives annual rain fall of 2000 to $3500 \mathrm{~mm}$ spread over 4-5 months (Jan-Sept) with temperature $\left(27^{\circ} \mathrm{C}\right)$ and RH $(80$ $\%)$. Experiment was laid out in Complete Randomised Design with 7 anthurium cultivars viz., Tropical, Middori, Cheers, Crinkle Red, Fantasia and Acropolis and replicated thrice for cut flower production in raised bed during 2013-2016 under NVPH. The bed comprised of coconut husk, coffee pulp, coir pith, brick pieces and tile pieces. Pooled Data on vegetative parameters viz; plant height, number of leaves, leaf area, Leaf Area Index), flowering parameters viz; days taken for unfolding of spathe from initiation of flowers, number of days taken for full unfolding of spathe from initiation of flower and vase life), quality parameters viz; peduncle length, spathe length, spadix length, spadix angle to spathe and yield parameters viz; number of flowers per plant were recorded at monthly interval from six months after planting. 
Vegetative characters were significantly influenced by the cultivars (Table1). Maximum plant height was recorded in cultivar Tropical $(73.12 \mathrm{~cm})$ and it was on par with $c v$. Fire $(64.22 \mathrm{~cm})$ and Cheers $(60.13 \mathrm{~cm})$ and least plant height was recorded in $c v$. Fantasia $(30.63 \mathrm{~cm})$. With respect to number of leaves cv. Midori recorded highest number of leaves (13.44) which was at par with $c v$. Tropical (12.56) and $c v$. Fire (12.23) and lowest o leaves were recorded in $c v$. Fantasia (5.43). Cultivar Tropical recorded maximum petiole length (36.15 $\mathrm{cm})$ and it was minimum in $c v$. Fantasia (19.25). For leaf area and Leaf Area Index, $c v$. Crinkle Red
(2662.00 $\left.\mathrm{cm}^{2}\right)$ was at par with $c v$. Tropical $\left(2585.00 \mathrm{~cm}^{2}\right)$ and it was least in $c v$. Fantasia $\left(955,00 \mathrm{~cm}^{2}\right)$, While, LAI is concerned $c v$. Tropical recorded maximum LAI 2.83, followed by Midori 2.49 and least was in Fantasia 1.0. Cultivar Tropical was aggressive in vegetative growth so it had maximum plant height, number of leaves, leaf area and so also maximum Leaf area Index hence maximum photosyntates. This may also be attributed to the interaction between environment. While $c v$. Fantasia recorded least LAI with least plant height, number of leaves and leaf area. These findings are in line with findings of Femina et al (2006)

Table 1. Vegetative parameters as influenced by different Anthurium cultivars (pooled data 3 years)

\begin{tabular}{|l|c|c|c|c|c|}
\hline \multicolumn{1}{|c|}{ Treatment } & $\begin{array}{c}\text { Plant height } \\
(\mathrm{cm})\end{array}$ & $\begin{array}{c}\text { Number of } \\
\text { leaves }\end{array}$ & $\begin{array}{c}\text { Leaf area } \\
(\mathrm{cm} 2)\end{array}$ & LAI & $\begin{array}{c}\text { Petiole length } \\
(\mathrm{cm})\end{array}$ \\
\hline $\mathrm{V}_{1}:$ Fantasia & 29.88 & 5.48 & 953.00 & 1.13 & 19.92 \\
\hline $\mathrm{V}_{2}:$ Acropolis & 43.68 & 8.94 & 1617.67 & 1.73 & 26.67 \\
\hline $\mathrm{V}_{3}:$ Crinkle Red & 55.76 & 10.64 & 2662.33 & 3.43 & 26.50 \\
\hline $\mathrm{V}_{4}:$ Tropical Red & 72.04 & 12.69 & 2585.00 & 2.93 & 36.72 \\
\hline $\mathrm{V}_{5}:$ Fire & 64.07 & 11.91 & 1790.00 & 2.00 & 30.63 \\
\hline $\mathrm{V}_{6}:$ Cheers & 59.71 & 7.97 & 1512.33 & 1.95 & 27.16 \\
\hline $\mathrm{V}_{7}:$ Midori & 55.67 & 13.22 & 2306.00 & 2.66 & 33.59 \\
\hline S. Em \pm & 0.45 & 0.54 & 1.48 & 0.27 & 0.51 \\
\hline$C D(P=0.05)$ & 1.39 & 1.68 & 4.57 & 0.84 & 1.58 \\
\hline
\end{tabular}

Significant difference was observed for flowering, quality and yield parameters. The pooled data is presented in (Table 2). Cultivar Fantasia (50.54 days) took minimum days for unfolding of spathe from initiation, while $c v$. Tropical (73.12 days) took maximum days which was at par with Fire (64.22 days) and Cheers (60.13 days). Peduncle length is most important character which decides the suitability as cut flower and price of any anthurium variety, Cultivar Tropical had $(63.50 \mathrm{~cm})$ peduncle length being highest among the cultivars followed by Cheers and Fire. Cultivar Fantasia recorded minimum peduncle length $(28.23 \mathrm{~cm})$. Another important quality parameter that makes cultivar suitable for export is Spadix angle to spathe. Similar results were also reported by Rajeevan et al (2007) in Anthurium. If angle is wide there is chance of breakage of spadix in packing so an angle of around $30^{\circ}$ is ideal. Cultivar Tropical had an angle of $32{ }^{\circ}$ which was on par with Fire with an angle of $32.25^{\circ}$ and Crinkle Red and
Acropollis had maximum angle of $44.10^{\circ}$ and $43.20^{\circ}$ respectively. Femina et al (2006) also reported variation in spadix angle in Anthurium cultivars studied.

Main objective of protected cultivation is to have more number of flowers per square meter, significant differences were observed for yield parameters. Cultivar Crinkle Red statistically recorded maximum number of flowers per plant per year (13.14), which was on par with Tropical (11.77), Cheers (10.60), Fire (10.25) and least was in Fantasia (8.1). Cultivar Midori recorded maximum vase life (35.00 days), followed by Tropical (33.33 days) and it was on par with Fire (32.22 days), least vase life was recorded in $c v$. Acropolis with 19.00 days. Earlier Latha et al (2015) showed similar results in variety 'Esmeralda'. Similar results were also recorded by Paull and Chantrachit (2001) and Thawiang et al (2007). Though the $c v$. Crinkle Red had maximum flowers but quality parameters like peduncle length, spadix 
angle was more hence not suitable for export hence can only be sold in local market. Whereas, Tropical had appreciable vegetative, quality, flowering and yield parameters along with maximum plant height, number of leaves, highest peduncle length, leaf area, LAI which was able to synthesize more photosynthates and thus produced better quality flowers, more yield and maximum vase life. Similar results were also reported by Islam et al (2013) in Anthurium. Significant difference were reported for $\mathrm{B}: \mathrm{C}$ ratio (Table 3.) among all cultivars, cost of cultivation was 4,12,539.00 for 560 sq.mt and yield varied from 40,500 in Cv. Fantasia to 58,850 in $\mathrm{Cv}$. Tropical accordingly gross and net returns were varied from 7,55,280 to $3,42,741$ . cultivar Tropical recorded maximum B:C ratio (1.83) followed by Cheers (1.64), Fire (1.51) and it was least in Fantasia (1.13), these difference may be attributed to yield potential and quality of flowers of individual genotypes, similar results were also reported by Agasimani et al., (2011).

Table 2. Flower, quality and yield parameters as influenced by Anthurium cultivars (pooled data 3yrs)

\begin{tabular}{|l|c|c|c|c|c|c|c|c|c|c|}
\hline Treatment & $\begin{array}{c}\text { Days to } \\
\text { intiate bud } \\
\text { to flowering }\end{array}$ & $\begin{array}{c}\text { Peduncle } \\
\text { length } \\
(\mathrm{cm})\end{array}$ & $\begin{array}{c}\text { Spathe } \\
\text { length } \\
(\mathrm{cm})\end{array}$ & $\begin{array}{c}\text { Spathe } \\
\text { width } \\
(\mathrm{cm})\end{array}$ & $\begin{array}{c}\text { Spadix } \\
\text { angle to } \\
\text { spathe }\end{array}$ & $\begin{array}{c}\text { Spadix } \\
\text { length } \\
(\mathrm{cm})\end{array}$ & $\begin{array}{c}\text { Spadix } \\
\text { width } \\
(\mathrm{mm})\end{array}$ & $\begin{array}{c}\text { Flowering } \\
\text { duration } \\
(\text { days })\end{array}$ & $\begin{array}{c}\text { Number } \\
\text { of flowers/ } \\
\text { plant/year }\end{array}$ & $\begin{array}{c}\text { Vase } \\
\text { life } \\
(\mathrm{days})\end{array}$ \\
\hline $\mathrm{V}_{1}:$ Fantasia & 50.54 & 28.08 & 10.55 & 7.81 & 35.03 & 3.60 & 7.84 & 57.11 & 8.1 & 28.00 \\
\hline $\mathrm{V}_{2}:$ Acropolis & 44.09 & 43.07 & 13.56 & 9.47 & 34.13 & 4.87 & 7.78 & 48.22 & 10.08 & 19.70 \\
\hline $\mathrm{V}_{3}:$ Crinkle Red & 56.21 & 44.03 & 10.55 & 9.45 & 29.07 & 4.56 & 7.00 & 58.44 & 13.41 & 24.89 \\
\hline $\mathrm{V}_{4}:$ Tropical Red & 73.15 & 63.17 & 15.01 & 10.59 & 32.00 & 6.52 & 9.94 & 61.22 & 11.77 & 32.78 \\
\hline $\mathrm{V}_{5}:$ Fire & 64.26 & 56.30 & 13.87 & 9.61 & 32.42 & 5.58 & 8.87 & 58.67 & 10.25 & 32.41 \\
\hline $\mathrm{V}_{6}:$ Cheers & 60.12 & 47.27 & 9.53 & 8.06 & 28.30 & 3.60 & 7.53 & 64.22 & 10.60 & 30.11 \\
\hline $\mathrm{V}_{7}:$ Midori & 56.14 & 59.15 & 13.36 & 11.19 & 30.04 & 5.46 & 8.53 & 94.11 & 9.05 & 35.17 \\
\hline $\mathrm{S}$. Em \pm & 0.54 & 0.63 & 0.34 & 0.35 & 0.65 & 0.33 & 0.37 & 0.68 & 0.58 & 0.57 \\
\hline$C D(P=0.05)$ & 1.65 & 1.93 & 1.06 & 1.09 & 2.02 & 1.00 & 1.16 & 2.10 & 1.95 & 1.75 \\
\hline
\end{tabular}

Table 3. Economics of Anthurium cultivars during II year

\begin{tabular}{|c|c|c|c|c|c|c|c|}
\hline \multirow[b]{2}{*}{ Cultivar } & \multirow{2}{*}{$\begin{array}{l}\text { Total cost of } \\
\text { cultivation for } \\
560 \text { sq.mt } \\
\text { (Rs.) }\end{array}$} & \multirow{2}{*}{$\begin{array}{l}\text { Flower } \\
\text { yield } \\
(560 \\
\text { sq.mt })\end{array}$} & \multicolumn{2}{|c|}{ Price per flower } & \multirow{2}{*}{$\begin{array}{l}\text { Gross return } \\
\text { (Rs.) * }\end{array}$} & \multirow{2}{*}{$\begin{array}{l}\text { Net returns } \\
\text { (Rs.) }\end{array}$} & \multirow{2}{*}{$\begin{array}{l}\mathrm{GBC} \\
\text { ratio }\end{array}$} \\
\hline & & & $\begin{array}{c}\text { A } \\
\text { grade }\end{array}$ & $\begin{array}{c}\text { B } \\
\text { Grade }\end{array}$ & & & \\
\hline $\mathrm{V}_{1}$ : Fantasia & $4,12,539.00$ & 40500 & 24300 & 16200 & $4,69,800.00$ & $57,261.00$ & 1.13 \\
\hline $\mathrm{V}_{2}:$ Acropolis & $4,12,539.00$ & 50500 & 30300 & 20200 & $5,85,800.00$ & $1,73,261.00$ & 1.41 \\
\hline $\mathrm{V}_{3}:$ Crinkle Red & $4,12,539.00$ & 67050 & 13410 & 53640 & $6,16,860.00$ & $2,04,321.00$ & 1.49 \\
\hline $\mathrm{V}_{4}:$ Tropical & $4,12,539.00$ & 58850 & 47080 & 11770 & $7,55,280.00$ & $3,42,741.00$ & 1.83 \\
\hline $\mathrm{V}_{5}:$ Fire & $4,12,539.00$ & 51250 & 35875 & 15375 & $6,25,250.00$ & $2,12,711.00$ & 1.51 \\
\hline $\mathrm{V}_{6}:$ Cheers & $4,12,539.00$ & 53000 & 42400 & 10600 & $6,78,400.00$ & $2,65,861.00$ & 1.64 \\
\hline $\mathrm{V}_{7}$ :Midori & $4,12,539.00$ & 45500 & 36400 & 9100 & $5,85,400.00$ & $1,72,861.00$ & 1.41 \\
\hline
\end{tabular}

- A grade flower average price Rs.14

- B grade flower average price is Rs.8/flower is the Cost of flower considered for calculation 


\section{Establishment cost for Anthurium grown under naturally ventilated polyhouse of $560 \mathrm{~m}^{2}$ area}

\begin{tabular}{|c|c|c|c|}
\hline $\begin{array}{l}\text { Particulars } \\
\text { Remarks }\end{array}$ & Total cost & Amortized cost & (Rs./year) \\
\hline \multicolumn{4}{|l|}{ I. Investment cost } \\
\hline $\begin{array}{l}\text { Construction of polyhouse (for life } \\
\text { of } 15 \text { years) }\end{array}$ & $4,000,00.00$ & $26,600.00$ & $\begin{array}{l}\text { With drip and ventury } \\
\text { system }\end{array}$ \\
\hline $\begin{array}{l}\text { Planting materials@100/plant for } 4 \\
\text { years (5000 plants/450 sq.mt net } \\
\text { cultivable area ) }\end{array}$ & $4,90,000.00$ & $1,22,500.00$ & $\begin{array}{l}80 \% \text { area is the actual } \\
\text { planting area after excluding } \\
\text { paths and hockey }(20 \%)\end{array}$ \\
\hline $\begin{array}{l}\text { Bed preparation (tiles, bricks, } \\
\text { coconut husk, coir pith) for four } \\
\text { years }\end{array}$ & $50,000.00$ & $12,500.00$ & Apportioned for 4 years \\
\hline Sub total & $9,40,000.00$ & $1,61,600.00$ & Polyhouse-15 yrs Plants-4 yrs \\
\hline \multicolumn{4}{|l|}{ II. Maintenance cost for first year } \\
\hline $\begin{array}{l}\text { 1. Labour@ Rs.450/day labour for } \\
\text { bed preparation and planting } 20 \text { man } \\
\text { days }\end{array}$ & $9,000.00$ & & \\
\hline $\begin{array}{l}\text { Supervision and to operate drip and } \\
\text { fertigation unit ( } 2 \text { hrs a day) } 60 \text { man } \\
\text { days }\end{array}$ & $27,000.00$ & & \\
\hline $\begin{array}{l}\text { Spraying of PP chemicals @ } 2 \text { hr/ } 15 \\
\text { day/year=6 man days }\end{array}$ & 2700.00 & & \\
\hline $\begin{array}{l}\text { Intercultural operations Weeding, } \\
\text { harvesting, filling of media, } \\
\text { harvesting of flowers and packing of } \\
\text { flowers harvested in first year. } 2 \\
\text { labour/15 days for } 10 \text { months is } 40 \\
\text { man days }\end{array}$ & $18,000.00$ & & \\
\hline $\begin{array}{l}\text { 2. Fertilizers and plant protection } \\
\text { chemicals }\end{array}$ & $30,492.00$ & & \\
\hline 3. Irrigation & 5000.00 & & \\
\hline 4. Harvesting and packing & 10000.00 & & \\
\hline Total maintenance cost I year & $1,02,192.00$ & & \\
\hline Total return during I year & $\begin{array}{l}15000 \times 4 \\
= \\
60,000.00\end{array}$ & & $\begin{array}{l}3 \text { flowers/plant after six } \\
\text { months and sold @ Rs. 4/ } \\
\text { flower for C grade flower }\end{array}$ \\
\hline Maintenance cost I year & Rs.42,192.00 & Rs.10,548.00 & Apportioned for 4 years \\
\hline Total establishment cost & Rs.9,82,192.00 & $1,72,148.00$ & \\
\hline \multicolumn{4}{|c|}{ III. Cost of cultivation of Anthurium under NVPH polyhouse II year onwards } \\
\hline \multicolumn{4}{|l|}{ Variable cost } \\
\hline \multicolumn{4}{|l|}{ 1. Labour@ Rs.450/day } \\
\hline $\begin{array}{l}\text { a. Supervision and to operate drip } \\
\text { and fertigation unit ( } 2 \mathrm{hrs} \text { a day) } 40 \\
\text { man days }\end{array}$ & $18,000.00$ & & \\
\hline
\end{tabular}




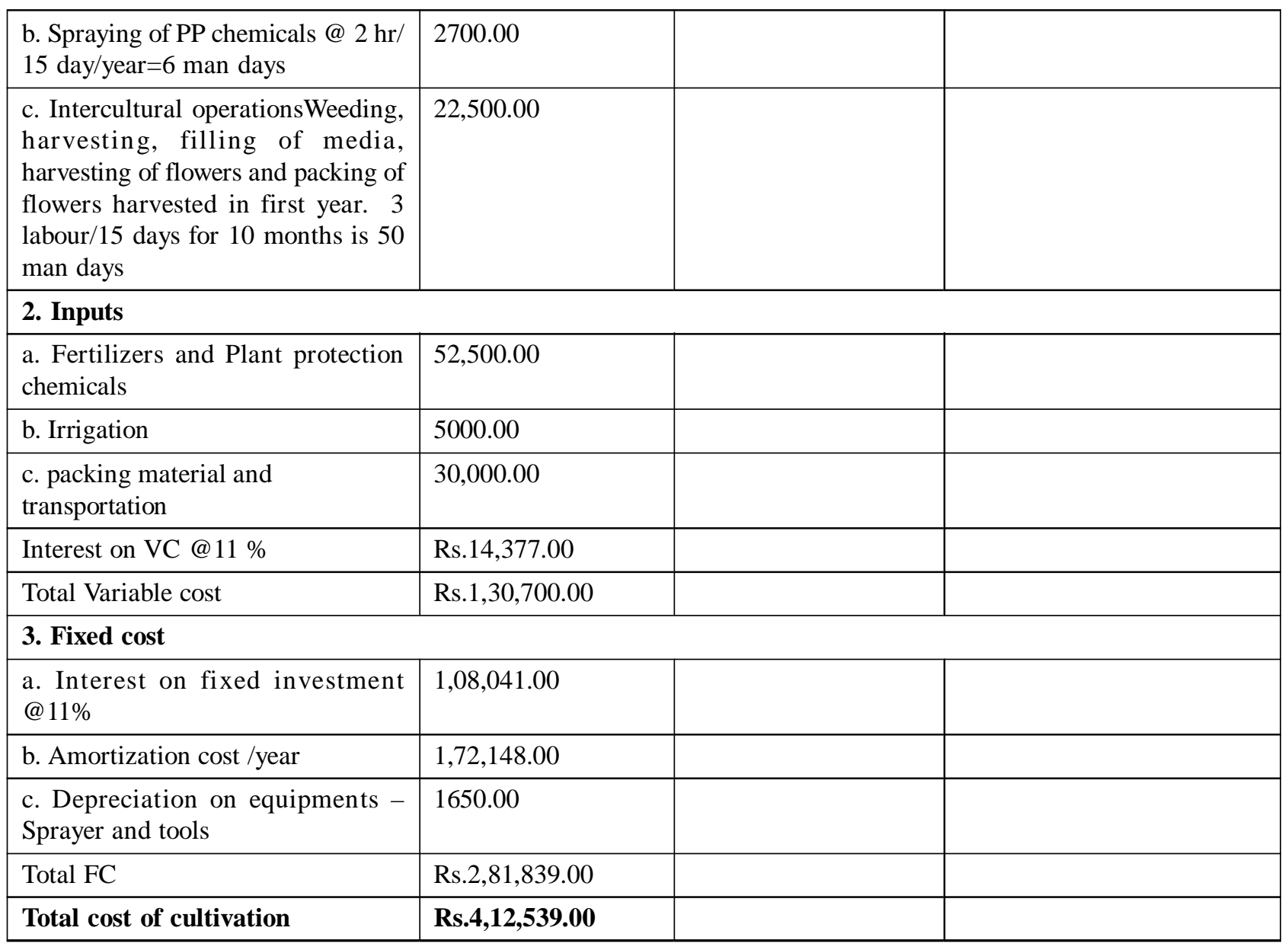




\section{REFERENCES}

Agasimani, A.D., Harish, D.K. and Imamsaheb, S.J.2011: Anthurium varieties performance and economics under greenhouse. Res. J. Agril. Sci., 2: 226-229.

Femina, Valsalakumari,P.K and Rajeevan, P. K. 2006, Performance of anthurium (Anthurium andreanum Linn.) cultivars under different systems of growing in humid tropical plains. J. Ornamental Hort. 9(4): 274-277.

Islam M.S., Mehraj, H., Roni, M.Z.K., Shahrin S. and Jamal Uddin A.F.M. 2013, Varietal study of anthurium (Anthurium andreanum) as a cut flower in Bangladesh. Journal of Bangladesh Academy of Sciences. 37 (1): 103-107.

Latha S, Reddy B.S and Sudeep H.P, 2015, Varietal performance, correlation studies and economics of anthurium cultivation under protected conditions, Res. Environ. Life Sci. 8(4): 773-776.

Paull, R. E. and T. Chantrachit, 2001, Benzyladenine and the vase life of tropical ornamentals. Postharvest Biol. Tech. 21(3): 303-310.
Prakash, D., Sujatha, K. and Sangma 2006.Anthurium. In: Advan. Orn. Hort. (Ed.,Bhattacharjee, S.K.). Pointer Publishers, Jaipur.pp. 109-29.

Rajeevan, P.K., Valasakumari, P.K., Rao, P.G.H., Liji, P.V and Sujitha, M, 2007, Performance evaluation of cut flower varieties of anthurium under two agro-climatic conditions. $J$. Ornamental Hort. 10(3): 177-180.

Shiva, K.N. and Sujatha A. Nair 2008. Performance of Anthurium (Anthurium andreanum Linden.) cultivars in Andamans. Indian $J$. Hort.,65(2):180-183.

Thawiang, N., Buanong, M. and Kanlayanarat, S, 2007, Effect of thidiazuron on postharvest quality of cut flowers of anthurium (Anthurium andreanum L. cv. Marshall). Acta Hort. 75(5): 415-418.

(MS Received 12 September 2017, Revised 06 November 2018, Accepted 30 March 2019) 